\title{
Recent Chinese Tax Legislation Affecting Foreign Investment in China
}

\author{
Gerald A. Wunsch* \\ and Dingfa Liu**
}

In April 1991, the National People's Congress of China passed the "Income Tax Law of the People's Republic of China for Enterprises with Foreign Investment ${ }^{1}$ and Foreign Enterprises"' (Foreign Investment Tax Law). At the same time, the National People's Congress repealed the "Income Tax Law of the People's Republic of China Concerning Joint Ventures with Chinese and Foreign Investment" (Joint Venture Income Tax Law) and the "Income Tax Law of the People's Republic of China Concerning Foreign Enterprises"' (Foreign Enterprise Income Tax Law). ${ }^{4}$ The new tax law became effective on July 1, 1991, and marked a major step in China's effort to further simplify the tax system affecting foreign investment and to improve the foreign investment climate as a whole. This Article briefly reviews

* Partner, Law Firm of Rund \& Wunsch, Indianapolis, Indiana

** Associate, Law Firm of Rund \& Wunsch, Indianapolis, Indiana; former Deputy Section Chief of International Tax Policy Division, National Tax Bureau, Peoples Republic of China (1986 - 1988).

1. "Enterprises with foreign investment" refers to Chinese-Foreign Joint Ventures, both equity and contractual, and to Wholly-Foreign Owned Enterprises incorporated in China. Income Tax Law of the Peoples Republic of China for Enterprises With Foreign INVESTMENT and Foreign ENTERPRises, art. 2 (1991) (see appendix) [hereinafter Foreign Investment Tax LAW].

2. "Foreign enterprises" are defined as foreign companies, enterprises and other economic organizations which engage in production or business through their establishments in China, and those which do not have establishments in China but derive income from sources within China. Id.

3. The Income Tax Law of the Peoples Republic of China Concerning Joint Ventures with Chinese and Foreign Investment (1980) (repealed 1991), reprinted in Price Waterhouse, Doing Business in the Peoples Republic of China 175-77 (1988) [hereinafter Joint Venture Income Tax Law]; Detailed Rules and Regulations for the Implementation of the Income Tax Law of the Peoples Republic of China Concerning Joint Ventures with Chinese and Foreign Investment (1980) (repealed 1991), reprinted in Price Waterhouse, supra, at 178-86 [hereinafter Joint Venture Income Tax Regulations].

4. The Income Tax law of the Peoples Republic of China Concerning Foreign Enterprises (1981) (repealed 1991), reprinted in Price Waterhouse, supta note 3, at 187-90 [hereinafter Foreign Enterprise Income Tax LaW]; Unofficial Translation of the Detailed Regulations for the Implementation of the Foreign Enterprise Income Tax LaW (1982) (repealed 1991), reprinted in Price Waterhouse, supra note 3, at 191-201 [hereinafter Foreign Enterprise Income Tax Regulations]. 
the historical background of the Chinese income tax system, distinguishes the old and new law, outlines the major changes brought about by the new legislation, analyzes the policy considerations behind the new legislation, and finally considers some practical implications for a hypothetical investor.

\section{Historical BaGkground}

China did not impose income taxes on business enterprises until 1978 when China began a series of economic reforms. The first income tax laws affected only collectively-owned enterprises and state-owned enterprises. Then in the early 1980's, China promulgated the Joint Venture Income Tax Law and the Foreign Enterprise Income Tax Law, both of which affected foreign investment in China. As a result of these laws, a dual tax system emerged in China that continues to exist today. Under this dual tax system, Chinese enterprises whose investments are limited to the domestic market are subject to one set of tax rules, while foreign corporations and "Enterprises with Foreign Investment" are governed by another set of tax rules.

Prior to July 1, 1991, there were also two corporate income tax laws affecting foreign investment in China. The Joint Venture Income Tax Law governed taxation of Chinese-Foreign Equity Joint Ventures (Equity Joint Ventures); whereas, the Foreign Enterprise Income Tax Law applied to Chinese-Foreign Contractual Joint Ventures (Contractual Joint Ventures) and to foreign companies doing business in China, whether or not through establishments there. Although these two income tax laws had many common provisions, they differed in scope of tax jurisdiction, rate structure, and tax incentive schemes.

\section{Prior LAW}

\section{A. Joint Venture Income Tax Law}

The Joint Venture Income Tax Law applied only to Equity Joint Ventures. Tax was assessed on the worldwide income of the Equity Joint Venture at a basic tax rate of $30 \%$ of taxable income. In addition, a local (provincial) surtax of $10 \%$ of the basic tax rate, or $3 \%$ of taxable income, was sometimes assessed. ${ }^{5}$ The local surtax, when cou-

5. Local governments had authority to waive the local surtax, and, in competing for foreign investment, frequently did. See Joint Venture Income Tax Regulations, supra note 3 , at art. 3 . 
pled with the basic rate, thus raised the overall effective tax rate to $33 \%$. Furthermore, a $10 \%$ withholding tax was imposed if a foreign investor repatriated his profits from the Equity Joint Venture. However, if the foreign investor reinvested his earnings in China for at least five years, he was entitled to a tax refund of $40 \%$ of the income tax paid on his share of income. ${ }^{6}$

An Equity Joint Venture, which expected to operate in China for ten years or more, could apply to the tax authorities for exemption from national income tax in the first two profit-making years ${ }^{7}$ and for a $50 \%$ reduction in national income tax in the subsequent three years. ${ }^{8}$ In addition, such a joint venture could, upon approval by the Ministry of Finance, be allowed a further discretionary tax credit of 15 to $30 \% .^{9}$

\section{B. Foreign Enterprise Income Tax Law}

The Foreign Enterprise Income Tax Law applied to Wholly-Foreign Owned Enterprises, to Contractual Joint Ventures, and to foreign companies doing business in China whether or not through establishments situated in China. The term "establishments" in the regulations referred to organizations, places, or business agents of the foreign company operating in China in one of the following forms: (a) management office; (b) branch; (c) representative office; (d) factory; (e) location where natural resources are being exploited; (f) location where contractual projects for construction, installation, assembly and exploration are based. ${ }^{10}$

Under the Foreign Enterprise Income Tax Law, foreign companies with an establishment in China were taxed differently from those without an establishment in China. An example of a foreign company lacking an establishment in China would be a U.S. corporation that had no Chinese office, but transfered technology to China. Foreign companies without an establishment, but with income such as interest, dividends, and/or royalties, were subject to a flat $20 \%$ withholding tax. The tax

6. Id. at art. 6 .

7. The "first profit making year" was defined in the regulations as the year in which a joint venture recognized profits after the accumulated operating losses from prior years had been used up. Id. at art. 5 .

8. Joint Venture Income TAX LAW, supra note 3, at art. 5.

9. Id. (discretionary tax credits were available for up to 10 years to joint ventures which engaged in such low-profit operations as farming and forestry, or which were located in remote, economically underdeveloped areas of China).

10. Foreign Enterprise Income Tax Regulations, supra note 4, at art. 2. 
base was the gross amount received by such corporations from a source within China.

Foreign companies with an establishment in China were taxed as nonresident companies. They were thus subject to Chinese income tax only on their income from production, business operations, and other sources within China. The tax rate for these companies was progressive, ranging from 20 to $40 \%$. The tax rate was as follows: ${ }^{11}$

\begin{tabular}{ll} 
Amount of Annual Taxable Income in $\mathrm{RMB}^{12}$ & Tax Rate \\
\hline 250,000 or less & $20 \%$ \\
250,000 to 500,000 & $25 \%$ \\
500,000 to 750,000 & $30 \%$ \\
750,000 to $1,000,000$ & $35 \%$ \\
Over $1,000,000$ & $40 \%$
\end{tabular}

In addition to this tax, a local surtax of $10 \%$ of taxable income was sometimes assessed. ${ }^{13}$ The local surtax could be reduced or waived altogether at the discretion of the local government if the foreign company was engaged in a small or low-profit operation in China. However, if the local surtax was not reduced or waived, the effective tax rate would be $10 \%$ higher than the basic income tax rate. For instance, if the applicable income tax rate was $20 \%$, the effective rate would be $30 \%$.

A foreign company scheduled to operate in agriculture, forestry, animal husbandry, or other low-profit industries for ten years or more could apply to the tax authorities for exemption from national income tax in the first profit-making year ${ }^{14}$ and for a $50 \%$ national income tax reduction in the second and third profit-making years. ${ }^{15}$ After the period referred to above, the Ministry of Finance could authorize such a low-profit industry an additional tax credit of 15 to $30 \%$ for a period of ten years. ${ }^{16}$

11. Foreign Enterprise Income Tax LaW, supra note 4, at art. 3.

12. Renminbi (RMB) is the Chinese currency, sometimes called Yuan. One U.S. dollar equals approximately 5.29 RMB as of December 31, 1991.

13. Foreign Enterprise Income Tax Law, supra note 4, at art. 4; see also supra note 5 and accompanying text.

14. The "first profit-making year" is the year in which a foreign enterprise recognized profits after the accumulated operating losses from prior years had been absorbed.

15. Foreign Enterprise Income Tax Law, supra note 4, at art. 5.

16. Id. 


\section{Major Changes Under the Foreign Investment Tax Law}

The new tax law ${ }^{17}$ effectively combines the Joint Venture Income Tax Law with the Foreign Enterprise Income Tax Law and brings about several important changes. First, the new law imposes a flat tax rate of $33 \%$ for all "Enterprises with Foreign Investment" and for foreign companies doing business in China through their establishments there. ${ }^{18}$ Under the new law, Contractual Joint Ventures, Wholly Foreign-Owned Enterprises and foreign companies doing business in China through their establishments are no longer subject to a progressive rate of 30 to $50 \% .^{19}$ Instead, they are subject to income tax at a rate of $33 \%$, regardless of the amount of their annual taxable income. ${ }^{20}$ Consequently, the effective tax burden for enterprises other than Equity Joint Ventures will be either higher or lower than before. Most "Enterprises with Foreign Investment" can expect a decrease of tax burden of up to $17 \%$. However, the tax burden of those with an annual taxable income of $250,000 \mathrm{RMB}$ or less will be increased by at least $3 \%$.

Second, the new law restructures tax incentive schemes under the prior law and codifies tax incentives found in previous administrative regulations. In doing so, the new law provides the same tax incentives for all "Enterprises with Foreign Investment." The law now limits tax incentives to manufacturing concerns, enterprises in Special Economic Zones and other enterprises in designated foreign investment areas. ${ }^{21}$ For instance, the new law provides that all "Enterprises with Foreign Investment," which engage in any manufacturing and agree to operate for at least ten years, shall be exempt from income tax altogether for the first two profit-making years and will then be allowed a $50 \%$

17. See supra note 1 and accompanying text.

18. Foreign Investment Tax Law, supra note 1, at art. 5. (This includes the $3 \%$ local surtax which goes to the local government. As under prior law, the local surtax can be waived by the local government).

19. Foreign Enterprise Income TaX LAW, supra note 4, at art. 3-4. (This includes the $10 \%$ local surtax which could be imposed by local [provincial] governments under the prior tax law.).

20. "Enterprises with Foreign Investment" established in Special Economic Zones and other designated foreign investment zones may be subject to national income tax at a reduced rate of 15 or $24 \%$. See genetally Foreign Investment Tax Law, supta note 1 , at art. 7 .

21. Special Economic Zones are geographic regions targeted by the Chinese government for foreign investment. The Chinese government provides special investment incentives to enterprises in Special Economic Zones and in other designated foreign investment zones. See generally Price WATERhouse, supta note 3, at 54-55. 
reduction in the national income tax for the next three years. ${ }^{22}$

Third, the new law sets forth a new standard for determining whether a company is a resident or nonresident for tax purposes. Under the prior law, only Equity Joint Ventures were tax residents and subject to taxation on worldwide income. The new law, however, provides that any enterprise with a head office in China is a resident of China for tax purposes and hence subject to Chinese income tax on its worldwide income. ${ }^{23}$

Fourth, the new law repeals the $10 \%$ withholding tax imposed under prior law on outgoing dividends of Equity Joint Ventures. ${ }^{24}$ Lastly, the new law introduces anti-tax evasion provisions. It authorizes the tax authorities to make reasonable adjustments if a transaction between affiliated companies is not made at arms length. ${ }^{25}$ Further it imposes, in cases of tax evasion, fines of up to $500 \%$ of the amount due and/or criminal penalties. ${ }^{26}$

\section{Policy Considerations Behind the New Tax Legislation}

In spite of its adherence to the socialist system, China is eager to absorb foreign investment. Over the past ten years, China has put in place considerable legislation affecting foreign investment. However, the legislation was piecemeal and resulted in some inconsistencies and a lack of coordination among various laws. In part, this prompted the new tax legislation.

The prior tax law was promulgated at a time when the ChineseForeign Joint Venture Law was the only corporate law governing foreign investment in China. Under that law, only Equity Joint Ventures were considered to be legal entities incorporated in China, and thus only

22. This changes prior tax law under which only Equity Joint Ventures were eligible for a two-year tax exemption and an additional three-year $50 \%$ tax reduction. Under the new law, all "Enterprises with Foreign Investment" are eligible for the above-mentioned tax exemption and reduction. However, the new law limits eligibility to manufacturing concerns. See Foreign Investment Tax LaW, supra note 1, at art. 8.

23. Prior tax law did not contemplate taxation of the worldwide income of Wholly-Foreign Owned Enterprises or Contractual Joint Ventures which had head offices in China. The new law streamlines the tax jurisdiction and puts Chinese domestic law in line with the new corporate law system and the provisions of tax treaties that China has with foreign countries. See generally Foreign Enterprise Income Tax Law, supra note 4, at art. 1; Foreign Investment TAX LAW, supra note 1, at art. 3.

24. See Foreign Investment Tax Law, supra note 1 , at art. 19.

25. Id. at art. 13.

26. Id. at art. 25 . 
they were taxed on worldwide income. However, after the promulgation of the Wholly-Foreign Owned Enterprise Law ${ }^{27}$ and the Chinese-Foreign Contractual Joint Venture Law, the prior tax law could no longer cope with the new corporation law system.

Under the Wholly-Foreign Owned Enterprise Law and the Contractual Joint Venture Law, "Wholly-Foreign Owned Enterprises" (Foreign Enterprises) and Contractual Joint Ventures, which are incorporated in China, are considered Chinese legal entities having their head office in China. Thus, they should be treated as resident companies and taxed on worldwide income. Accordingly, the new tax law provides that Foreign Enterprises and Contractual Joint Ventures shall be taxed on worldwide income.

The other major moving force behind the new tax legislation was the elimination of the disparate tax treatment of different forms of foreign investment. This disparity was created by the distinct rate structure and tax incentive schemes contained in prior tax laws. Under prior law, Equity Joint Ventures were subject to income tax at a maximum rate of $33 \%$, while Foreign Enterprises and Contractual Joint Ventures were subject to income tax at progressive rates of up to $50 \%$. Moreover, Equity Joint Ventures enjoyed greater tax benefits than the other business forms regardless of the nature of business conducted in China. These disparities in effect created artificial constraints on an investor's choice of business form in China, constraints which were not particularly beneficial to the investor or the Chinese government.

It is reasonable to assume that the Chinese government believed its tax rates, when compared to those of its Asian Rim neighbors, were too high to compete effectively for foreign investment. Chinese officials also came to the realization that tax incentive systems must be both industry-oriented and region-oriented. This overhaul of how China will tax foreign investment is seen in China as a key component of China's emerging foreign investment policy.

\section{Practical Implications}

The recent Chinese tax legislation has a significant impact on contemplated foreign investment in China. With its single tax rate and streamlined tax incentive schemes, it allows foreign investors greater flexibility in choosing their form of business. Investors no longer need

27. The Law of the Peoples Republic of China on Enterprises Operating Exclusively with Foreign Capital (1986), reprinted in Price Waterhouse, supra note 3 , at 203-06. 
to take into account different tax rates applicable to different business entities, unless they expect to derive an annual taxable income of $250,000 \mathrm{RMB}$ or less. ${ }^{28}$ The focus is now where to invest and in what projects to invest in order to get the best tax incentives.

One example will illustrate how China's new tax law might influence a typical investor's decisions. Company A, a U.S. meter equipment manufacturer, desires to set up a plant in China to manufacture meter equipment and export more than $70 \%$ of its products to Asian Rim countries and back to the United States. Company A agrees to maintain its investment in China for ten years. All other things being equal, Company A should choose to incorporate a subsidiary in China and locate its subsidiary in one of the Special Economic Zones. In doing so, Company A maximizes its tax benefits. By being in a Special Economic Zone, Company A's subsidiary will be subject to only $15 \%$ national income $\operatorname{tax}^{29}$ and $3 \%$ local surtax. If it exports more than $70 \%$ in a tax year, the subsidiary is subject to only $10 \%$ national income tax.$^{30}$ Furthermore, assuming the local government agrees to waive the local surtax, the subsidiary will be entirely exempt from income tax in its first two profit-making years by virtue of agreeing to maintain a manufacturing concern for ten years. ${ }^{31}$

\section{Conclusion}

The recent Chinese legislation affecting foreign investment is of far-reaching significance. It will direct foreign investment to locations and projects China desires. At the same time, it will enable foreign investors to choose forms of business without concern for disparate tax treatment.

28. See supra tax table and local surtax explanation at p. 4. (Under the prior Foreign Enterprise Income Tax Law, "Enterprises with Foreign Investment," other than Equity Joint Ventures, were subject to income tax at progressive rates of up to $50 \%$.).

29. Foreign InVestment Tax LaW, supra note 1 , at art. 7.

30. Detailed Regulations for the Implementation of the Income Tax Law of the Peoples Republic of China for Enterprises with Foreign Investment and Foreign ENTERPRises, art. 75, 17 (1991) (Chinese text on file with author). English translation will be reprinted in Price Waterhouse, Doing Business in the People's Republic of China (forthcoming 1992).

31. Foreign Investment Tax Law, supra note 1 , at art. 8. 


\section{Appendix}

Income Tax Law of The People's Republic of China for Enterprises With Foreign Investment and Foreign ENTERPRISES

\section{(Author's Unofficial Translation)}

Article 1: Income tax shall be paid in accordance with the provisions of this Law by enterprises with foreign investment within the territory of the People's Republic of China on their income derived from production, business operations and other sources.

Income tax shall be paid in accordance with the provisions of this Law by foreign enterprises on their income derived from production, business operations and other sources within the territory of the People's Republic of China.

Article 2: "Enterprises with foreign investment" referred to in this Law means Chinese-foreign equity joint ventures, Chinese-foreign contractual joint ventures and foreign-capital enterprises that are established in China.

"Foreign enterprises" referred to in this Law means foreign companies, enterprises and other economic organizations which have establishments or places in China and engage in production or business operations, and which, though without establishments or places in China, have income from sources within China.

Article 3: Any enterprise with foreign investment which establishes its head office in China shall pay its income tax on its income derived from sources inside and outside China. Any foreign enterprise shall pay its income tax on its income derived from sources within China.

Article 4: The taxable income of an enterprise with foreign investment and an establishment or a place set up in China to engage in production or business operations by a foreign enterprise, shall be the amount remaining from its gross income in a tax year after the cost, expenses and losses have been deducted.

Article 5: The income tax on enterprises with foreign investment and the income tax which shall be paid by foreign enterprises on the income of their establishments or places set up in China to engage in production or business operations shall be computed on the taxable income at the rate of thirty percent, and a local income tax shall be 
computed on the taxable income at the rate of three percent.

Article 6: The state shall, in accordance with the industrial policies, guide the orientation of foreign investment and encourage the establishment of enterprises with foreign investment which adopt advanced technology and equipment and export all or greater part of their products.

Article 7: The income tax on enterprises with foreign investment established in Special Economic Zones, foreign enterprises which have establishments or places in Special Economic Zones engaged in production or business operations, and enterprises with foreign investment of a production nature in Economic and Technological Development Zones, shall be levied at the reduced rate of fifteen percent.

The income tax on enterprises with foreign investment of a production nature established in coastal economic open zones or in the old urban districts of cities where the Special Economic Zones or the Economic and Technological Development Zones are located, shall be levied at the reduced rate of twenty-four percent.

The income tax on enterprises with foreign investment in coastal economic open zones, in the old urban districts of cities where the Special Economic Zones or the Economic and Technological Development Zones are located or in other regions defined by the State Council, within the scope of energy, communications, harbour, wharf or other projects encouraged by the state, may be levied at the reduced rate of fifteen percent. The specific rules shall be regulated by the State Council.

Article 8: Any enterprise with foreign investment of a production nature scheduled to operate for a period of not less than ten years shall, from the year beginning to make profit, be exempted from income tax in the first and second years and allowed a fifty percent reduction in the third to fifth years. However, the income tax exemption or reduction for enterprises with foreign investment engaged in the exploitation of resources such as petroleum, natural gas, rare metals, and precious metals shall be regulated separately by the State Council. Enterprises with foreign investment which actually operate for a period less than ten years, shall repay the amount of income tax exempted or reduced.

The relevant regulations, promulgated by the State Council before the entry into force of this Law, which provide preferential treatment of exemption from or reduction of income tax on enterprises engaged in energy, communications, harbour, wharf and other major projects 
of a production nature for a period longer than that specified in the preceding paragraph, or which provide preferential treatment of exemption from or reduction of income tax on enterprises engaged in major projects of a non-production nature, shall remain applicable after this Law enters into force.

Any enterprise with foreign investment which is engaged in agriculture, forestry or animal husbandry and any other enterprise with foreign investment which is established in remote underdeveloped areas may, upon approval by the competent department for tax affairs under the State Council of an application filed by the enterprise, be allowed a fifteen to thirty percent reduction of the amount of income tax payable for a period of another ten years following the expiration of the period for tax exemption and reduction as provided for in the preceding two paragraphs.

After this Law enters into force, any modification to the provisions of the preceding three paragraphs of this Article on the exemption or reduction of income tax on enterprises shall be submitted by the State Council to the Standing Committee of the National People's Congress for decision.

Article 9: The exemption or reduction of local income tax on any enterprise with foreign investment which operates in an industry or undertakes a project encouraged by the state shall, in accordance with the actual situation, be at the discretion of the people's government of the province, autonomous region or municipality directly under the Central Government.

Article 10: Any foreign investor of an enterprise with foreign investment which reinvests its share of profit obtained from the enterprise directly into that enterprise by increasing its capital, or uses the profit as capital investment to establish other enterprises with foreign investment to operate for a period of not less than five years shall, upon approval by the tax authorities of an application filed by the investor, be refunded forty percent of the income tax already paid on the reinvested amount. Where other preferential provisions are provided by the State Council, such provisions shall apply. If the investor withdraws its reinvestment before the expiration of a period of five years, it shall repay the refunded tax.

Article 11: Losses incurred in a tax year by any enterprise with foreign investment and by an establishment or a place set up in China by a foreign enterprise to engage in production or business operations may be made up by the income of the following tax year. Should the 
income of the following tax year be insufficient to make up for the said losses, the balance may be made up by its income of the further subsequent year, and so on, over a period not exceeding five years.

Article 12: Any enterprise with foreign investment shall be allowed, when filing a consolidated income tax return, to deduct from the amount of tax payable the foreign income tax already paid abroad in respect of the income derived from sources outside China. The deductible amount shall, however, not exceed the amount of income tax otherwise payable under this Law in respect of the income derived from sources outside China.

Article 13: The payment or receipt of charges or fees in business transactions between an enterprise with foreign investment, or an establishment or a place set up in China by a foreign enterprise to engage in production or business operations, and its associated enterprises, shall be made in the same manner as the payment or receipt of charges or fees in business transactions between independent enterprises. Where the payment or receipt of charges or fees is not made in the same manner as in business transactions between independent enterprises and results in a reduction of the taxable income, the tax authorities shall have the right to make reasonable adjustments.

Article 14: Where an enterprise with foreign investment or an establishment or a place set up in China by a foreign enterprise to engage in production or business operations is established, moves to a new site, merges with another enterprise, breaks up, winds up or makes a change in any of the main entries of registration, it shall present the relevant documents to and go through tax registration with, the local tax authorities after the relevant event is registered with or a change or cancellation in registration is made by the administrative agency for industry and commerce.

Article 15: Income tax on enterprises and local income tax shall be computed on an annual basis and paid in advance in quarterly installments. Such payments shall be made within fifteen days from the end of each quarter and the final settlement shall be made within five months from the end of each tax year. Any excess payment shall be refunded and any deficiency shall be repaid.

Article 16: Any enterprise with foreign investment and any establishment or place set up in China by a foreign enterprise to engage in production or business operations shall file its quarterly provisional 
income tax return in respect of advance payments with the local tax authorities within the period of advance payments of tax, and it shall file an annual income tax return together with the final accounting statements within four months from the end of the tax year.

Article 17: Any enterprise with the foreign investment and any establishment or place set up in China by a foreign enterprise to engage in production or business operations shall submit its financial and accounting systems to the local tax authorities for reference. All accounting records must be complete and accurate, with legitimate vouchers as the basis for entries.

If the financial and accounting bases adopted by an enterprise with foreign investment and an establishment or a place set up in China by a foreign enterprise to engage in production or business operations contradict the relevant tax provisions of the State Council, tax payment shall be computed in accordance with the relevant tax provisions of the State Council.

Article 18: When any enterprise with foreign investment goes into liquidation, and if the balance of its net assets or the balance of its remaining property after deduction of the enterprise's undistributed profit, various funds and liquidation expenses exceeds the enterprise's paid-in capital, the excess portion shall be liquidation income on which income tax shall be paid in accordance with the provisions of this Law.

Article 19: Any foreign enterprise which has no establishment or place in China but derives profit, interest, rental, royalty and other income from sources in China, or though it has an establishment or place in China, the said income is not effectively connected with such establishment or place shall pay an income tax of twenty percent on such income.

For the payment of income tax in accordance with the provisions of the preceding paragraph, the income beneficiary shall be the taxpayer and the payor shall be the withholding agent. The tax shall be withheld from the amount of each payment by the payor. The withholding agent shall, within five days, turn the amount of taxes withheld on each payment over to the State Treasury and submit a withholding income tax return to the local tax authorities.

Income tax shall be reduced or exempted on the following income: (1) The profit derived by a foreign investor from an enterprise with foreign investment shall be exempted from income tax; 
(2) Income from interest on loans made to the Chinese government or Chinese state banks by international financial organizations shall be exempted from income tax;

(3) Income from interest on loans made at a preferential interest rate to Chinese state banks by foreign banks shall be exempted from income tax; and

(4) Income tax of the royalty received from the supply of technical know-how in scientific research, exploitation of energy resources, development of the communications industries, agricultural, forestry and animal husbandry production, and the development of important technologies may, upon approval by the competent department for tax affairs under the State Council, be levied at the reduced rate of ten percent. Where the technology supplied is advanced or the terms are preferential, exemption from income tax may be allowed.

Where the preferential treatment of reduction and exemption of income tax on profit, interest, rental, royalty and other income other than those provided for in this Article is required, it shall be regulated by the State Council.

Article 20: The tax authorities shall have the right to inspect the financial, accounting and tax affairs of enterprises with foreign investment and establishments or places set up in China by foreign enterprises to engage in production or business operations, and have the right to inspect tax withholding of the withholding agent and its payment of the withheld tax into the State Treasury. The entities inspected must report the facts and provide relevant information. They may not refuse to report or conceal any facts.

When making an inspection, the tax officials shall produce their identity documents and be responsible for confidentiality.

Article 21: Income tax payable according to this Law shall be computed in terms of Renminbi (RMB). Income in foreign currency shall be converted into Renminbi according to the exchange rate quoted by the state exchange control authorities for purposes of tax payment.

Article 22: If any taxpayer fails to pay tax within the prescribed time limit, or if the withholding agent fails to turn over the tax withheld within the prescribed time limit, the tax authorities shall, in addition to setting a new time limit for tax payment, impose a surcharge for overdue payment, equal to 0.2 percent of the overdue tax for each day in arrears, starting from the first day the payment becomes overdue. 
Article 23: The tax authorities shall set a new time limit for registration or submission of documents and may impose a fine of five thousand yuan or less on any taxpayer or withholding agent which fails to go through tax registration or make a change or cancellation in registration with the tax authorities within the prescribed time limit, fails to submit income tax return, final accounting statements or withholding income tax return to the tax authorities within the prescribed time limit, or fails to submit its financial and accounting systems to the tax authorities for reference.

Where the tax authorities have set a new time limit for registration or submission of documents, they shall impose a fine of ten thousand yuan or less on the taxpayer or withholding agent which again fails to meet the time limit for going through registration or making a change in registration with the tax authorities, or for submitting income tax return, final accounting statements or withholding income tax return to the tax authorities. Where the circumstances are serious, the legal representative and the person directly responsible shall be prosecuted for their criminal liability, by applying mutatis mutandis the provisions of Article 121 of the Criminal Law.

Article 24: Where the withholding agent fails to fulfil its obligation to withhold tax as provided in this Law, and does not withhold or withholds an amount less than that should have been withheld, the tax authorities shall set a time limit for the payment of the amount of tax that should have been withheld, and may impose a fine up to but not exceeding 100 percent of the amount of tax that should have been withheld.

Where the withholding agent fails to turn the tax withheld over to the State Treasury within the prescribed time limit, the tax authorities shall set a time limit for turning over the taxes and may impose a fine of five thousand yuan or less on the withholding agent; if the withholding agent fails to meet the time limit again, the tax authorities shall pursue the taxes according to law and may impose a fine of ten thousand yuan or less on the withholding agent. If the circumstances are serious, the legal representative and the person directly responsible shall be prosecuted for their criminal liability by applying mutatis mutandis the provisions of Article 121 of the Criminal Law.

Article 25: Where any person evades tax by deception or concealment or fails to pay tax within the time limit prescribed by this Law and, after the tax authorities pursued the payment of tax, fails again to pay it within the prescribed time limit, the tax authorities shall, in 
addition to recovering the tax which should have been paid, impose a fine up to but not exceeding five hundred percent of the amount of tax which should have been paid. Where the circumstances are serious, the legal representative and the person directly responsible shall be prosecuted for their criminal liability by applying the provisions of Article 121 of the Criminal Law.

Article 26: Any enterprise with foreign investment, foreign enterprise or withholding agent, in case of a dispute with the tax authorities on payment of tax, must pay tax according to the relevant regulations first. Thereafter, the taxpayer or withholding agent may, within sixty days from the date of receipt of the tax payment certificate issued by the tax authorities, apply to the tax authorities at the next higher level for reconsideration. The higher tax authorities shall make a decision within sixty days after receipt of the application for reconsideration. If the taxpayer or withholding agent is not satisfied with the decision, it may institute legal proceedings in the people's court within fifteen days from the date of receipt of the notification on decision made after reconsideration.

If the party concerned is not satisfied with the decision on punishment by the tax authorities, it may, within fifteen days from the date of receipt of the notification on punishment, apply for reconsideration to the tax authorities at the next higher level than that which made the decision on punishment. Where the party is not satisfied with the decision made after reconsideration, it may institute legal proceedings in the people's court within fifteen days from the date of receipt of the decision made after reconsideration. The party concerned may, however, directly institute legal proceedings in the people's court within fifteen days from the date of receipt of the notification on punishment. If the party concerned does not apply for reconsideration to the higher tax authorities or institute legal proceedings in the people's court within the time limit, and if the decision on punishment is not fulfilled, the tax authorities which made the decision on punishment may apply to the people's court for compulsory execution.

Article 27: Where any enterprise with foreign investment which was established before the promulgation of this Law would, in accordance with the provisions of this Law, otherwise be subject to higher tax rates or enjoy less preferential treatment of tax exemption or reduction than before the entry into force of this Law, in respect to such enterprise, within its approved period of operation, the Law and relevant regulations of the State Council in effect before the entry into force of this 
Law shall apply. If any such enterprise has no approved period of operation, the laws and relevant regulations of the State Council in effect before the entry into force of this Law shall apply within the period prescribed by the State Council. Specific rules shall be regulated by the State Council.

Article 28: Where the provisions of the tax agreements concluded between the government of the People's Republic of China and foreign governments are different from the provisions of this Law, the provisions of the agreements shall apply.

Article 29: Rules for implementation shall be formulated by the State Council in accordance with this Law.

Article 30: This Law shall enter into force on July 1, 1991. This Income Tax Law of the People's Republic of China for Chinese-Foreign Equity Joint Ventures and the Income Tax Law of the People's Republic of China for Foreign Enterprises shall be annulled on the same date. 
